\title{
Description of Dichelacera (Dichelacera) matogrossensis sp. nov. (Diptera, Tabanidae) of Brazilian Midwestern
}

\author{
Augusto L. Henriques' \& Tiago K. Krolow ${ }^{2}$
}

1. Coordenação de Pesquisas em Entomologia, Instituto Nacional de Pesquisas da Amazônia - INPA, Caixa Postal 2223, 69080-971, Manaus, AM, Brazil.
(augusto.inpa@gmail.com)
2. Coordenação de Ciências Biológicas, Universidade Federal do Tocantins - UFT, Caixa Postal 136, 77500-000, Porto Nacional, TO, Brazil. (tkkrolow@gmail.com)

ABSTRACT. Dichelacera matogrossensis sp. nov. is described based on females from the Chapada dos Guimarães, state of Mato Grosso, Brazil. Diagnosis, discussion and illustrations are provided.

KEY WORDS. Horse flies, Taxonomy, new species, Neotropics.

RESUMO. Descrição de Dichelacera matogrossensis sp. nov. (Diptera, Tabanidae) do centro-oeste brasileiro. Dichelacera matogrossensis sp. nov. é descrita baseada em fêmeas da Chapada dos Guimarães, estado do Mato Grosso, Brasil. São fornecidas diagnose, discussão e ilustrações.

PALAVRAS-CHAVE. Mutucas, taxonomia, nova espécie, Neotrópico.

According to recent Neotropical catalog (COSCARÓN \& PAPAVERo, 2009) Dichelacera Macquart, 1838, has five subgenera and 80 species, but HENRIQUES \& RAFAEL (1995) transferred 11 species of the subgenus Nothocanthocera Fairchild to genus Acanthocera Macquart, as noted in HENRIQUes et al. (2012), so in this sense, the genus has four subgenera and 69 species. Dichelacera (Dichelacera) was reviewed by FaIRCHILD \& PHILIP (1960), when the subgenus had 49 valid species. After this review the following species were included in group: $D$. amilcar Fairchild, 1964; $D$. brevidens Philip, 1976; D. quaesita Philip, 1976; D. xanthas Philip, 1976; D. amazonensis Henriques, 1995; D. paraensis Henriques, 1995; D. striata Henriques, 1995; D. tetradelta Henriques, 1995; D. corumbaensis Barros \& Gorayeb, 1995;D. anodonta Burger, 1999; D. auristriata Burger, 1999; D. fairchildi Burger, 1999; D. rubrofemorata Burger, 1999; D. variegata Burger, 1999; D. gemmae Limeira-de-Oliveira et al., 2009, and D. burgeri Coscarón \& Papavero, 2009, nom. nov. for D. aurata Burger, 1999. In addition, Dichelacera cearensis Fairchild \& Philip, 1960 was synonymized under $D$. varia (Wiedemann, 1828) by FAIRCHILD (1967). With these inclusions and the synonymy, the subgenus has 64 valid species.

This material examined here was obtained by recent systematic sampling conducted as part of a large project that aims is improvement the knowledge of Diptera in the Brazilian states of Mato Grosso, Mato Grosso do Sul and Rondônia. A new species of Tabanidae is described here.

\section{MATERIAL AND METHODS}

Depository institutions mentioned here are: Coleção de Entomologia da Universidade Federal de Tocantins, Campus Porto Nacional, Brazil (CEUFT); Florida State
Collection of Arthropods, Gainesville, USA (FSCA); Instituto Nacional de Pesquisas da Amazônia, Manaus, Brazil (INPA); Museu Paraense Emílio Goeldi, Belém, Brazil (MPEG); Museu de Zoologia da Universidade de São Paulo, Brazil (MZSP); Natural History Museum, London, England (BMNH) and Universidade Federal do Mato Grosso, Cuiabá, Brazil (UFMT). The frontal index (F.I.) and divergence index (D.I.) are according with FAIRCHILD (1985). Terminology is according Cumming \& Wood (2009) and Burger (2009). Dissection follows Cumming (1992) protocol. Specimens were examined and digitally photographed through a stereomicroscope coupled with an auto-montage system.

All specimens were fixed in alcohol first, the thorax and abdomen are somewhat crumpled and the pilosity are partly missing.

\section{RESULTS}

Dichelacera matogrossensis sp. nov.

(Figs 1-9)

Diagnosis. Frons with parallel sides. Face including frontoclypeal pits pruinose. Wing apex at most fumose contrasting with fascia brown, step-like. Posterior half of basal posterior and extreme base of discal cell brown infuscated. Interalar dark band of thorax wider than pale prescutellar band. Antennal spine not reaching second flagellomere. Flagellum subequal than distal segment of palpus.

Holotype female (Fig. 1). Length: $10.0 \mathrm{~mm}$. Wing: $10.3 \mathrm{~mm}$. Frons (Fig. 2) broad, parallel, with pale yellowish gray pruinosity and brown hairs, a distinct tubercle at vertex with vestiges of ocelli. D.I.: 1.0; F.I.: 3.0. Frontal callus 
yellowish brown, higher than wide, with short median prolongation above. Eyes bare, with two transversal bands. Subcallus, clypeus (face), parafacial and gena with yellowish pruinosity. Parafacial with whitish hairs. Gena with yellow hairs. Antennae (Fig. 4) with long dorsal spine, but not reaching the end of first flagellomere. Scape, pedicel and $1 / 2$ basal of first flagellomere brownish yellow, often the reminder darker. Palpus slender (Fig. 3), yellowish, with brown to black hairs. Labella and theca sclerotized, shiny brown (Fig. 3).

Scutum pale brown with yellowish gray pruinosity and yellow pilosity, a large dark brown interalar band and narrow yellowish pale prescutellar band. Scutellum brown with short brown hairs. Notopleural lobe yellowish gray with predominant yellowish hairs; pleura and sternum yellowish gray with yellowish hairs. Wing as figured (Fig. 5), inferior calyptra brown, halter pale yellow. All coxae pale yellow. Femora dark yellow. Fore tibiae bicolored, white with white hairs on proximal $2 / 3$ and brown with black hairs on apical 1/3. Mid tibiae white with pale hairs except for apical 1/4 pale brown with dark hairs. Hind tibiae and all tarsi brown with black hairs. Tergites $1-5$ brownish yellow with posterior whitish margins. Tergites 6-7 brown. Sternites pale brownish yellow with yellow hairs.

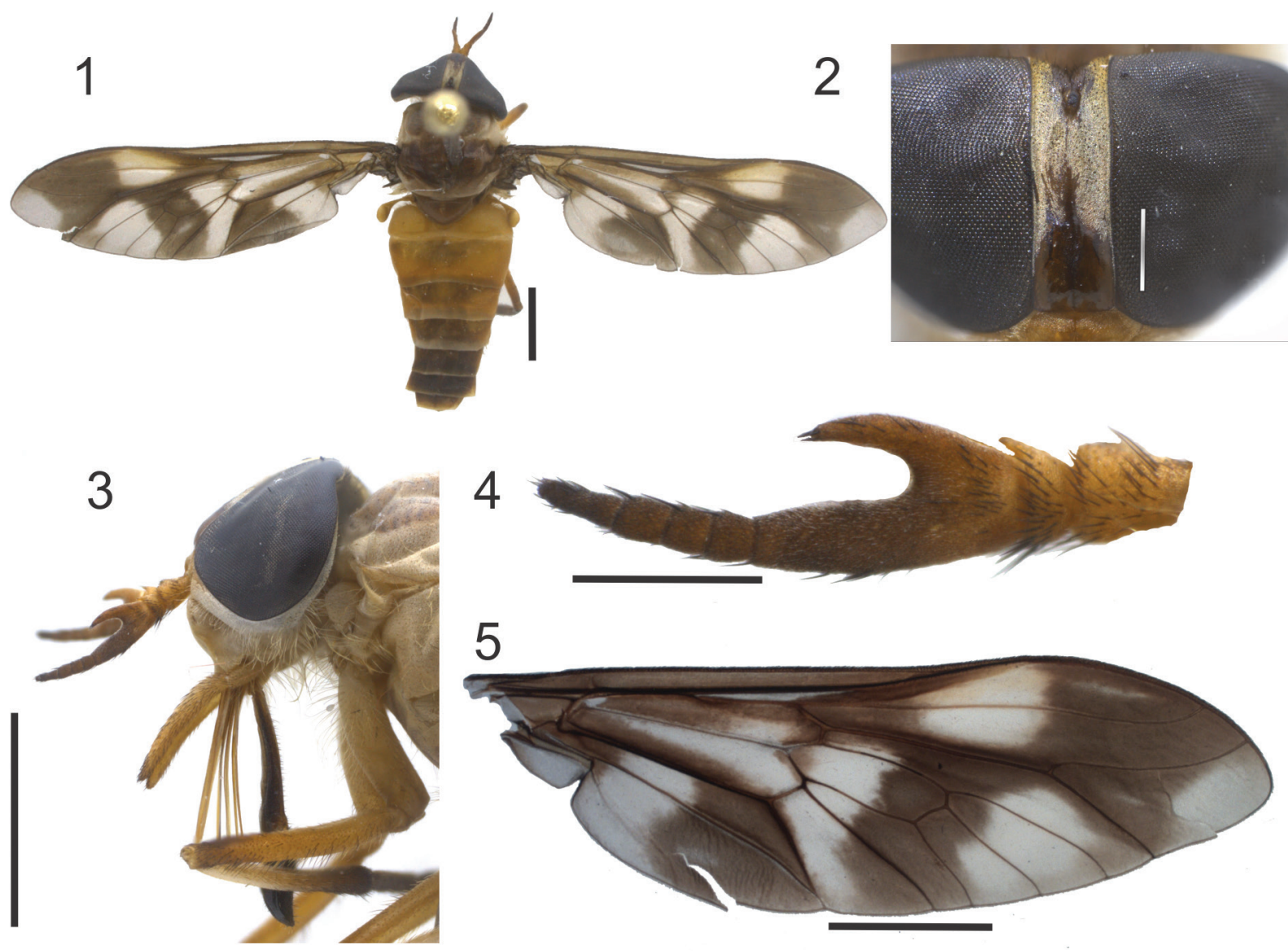

Figs 1-5. Dichelacera matogrossensis sp. nov., holotype female: 1, habitus, dorsal view; 2, frons, frontal view; 3, head, lateral view; 4, antenna, lateral view; 5 , wing, dorsal view. Scale bars: $1,3,5=2 \mathrm{~mm} ; 2,4=0.5 \mathrm{~mm}$.

Terminalia (Figs 6-9). Tergites IX and X, cercus and hypoproct as in Fig. 6. Tergite IX divided (not fused), partially destroyed but apparently subequal to tergite $\mathrm{X}$. Tergite $\mathrm{X}$ divided into two pieces, subrectangular. Cercus longer than large, with apex slightly acuminated. Hypoproct with apex acuminated, exceeding the half of the cercus length. Hypogynium + hypogynial valve (Fig. 7). Hypogynium with lateral margins slightly rounded, anterior and posterior margins little narrowed. Genital fork (Fig. 8) with reduced arms without distal expansions; tuft of setae on distal extremities of arms; anterior margin slightly excavated; sperm pump sclerotized with circular ridge expansions, shorter than genital fork. Spermathecal capsule slender, apex slightly acuminate and esclerotized, brown pigmented (Fig. 9).

Variations. Length: $9.9-10.3 \mathrm{~mm}(\mathrm{n}=5)$. Wing: $10.0-10.7(\mathrm{n}=5)$. D.I.: $0.95-1.0(\mathrm{n}=5)$; F.I.: $3.0-3.25$ $(\mathrm{n}=5)$. In some specimens the integument of tergites is dark on middle of anterior half.

Male: unknown.

Type Material. All pinned. Holotype female: BRAZIL, MT [Mato Grosso], (Parque Nacional Chapada

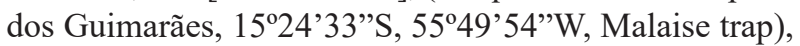
13.X-08.XI.2011, Lamas, Nihei eq. coll. (MZSP). Paratypes 

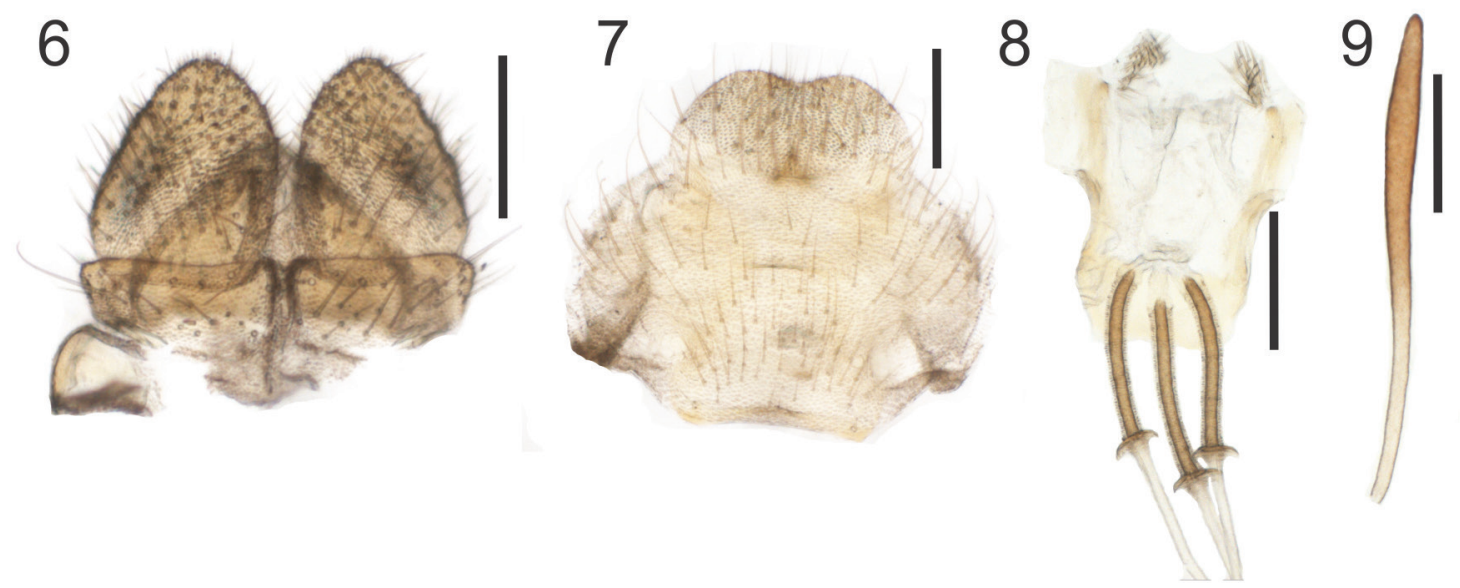

Figs 6-9. Dichelacera matogrossensis sp. nov., paratype (MZSP): 6, tergites IX and X, cerci and hypoproct, dorsal view; 7, hypogynium + hypogynial valve, dorsal view; 8, genital fork, dorsal view; 9, spermathecal capsule. Scale bars: $0.2 \mathrm{~mm}$.

all females: same data of holotype (2 INPA, 1 CEUFT); idem, 19.IX-13.X.2011 (3 MZSP, 1 MPEG, 1 FSCA, 1 BMNH, 1 UFMT).

Etymology. The specific name refers to the state of Brazil where the specimens was recorded, Mato Grosso.

\section{DISCUSSION}

Dichelacera matogrossensis sp. nov. is easily differentiated from other species of the Dichelacera (Dichelacera) by the darkening of the posterior half of the posterior basal cell and the base of the discal cell; this character is exclusive for this species in the subgenus. FAIRCHILD \& PHILIP (1960:7) at characterization of the genus commented: "The second basal cell and base of the discal cell are almost always hyaline, even in those cases where the wing is extensively infuscated".

Acknowledgments. To the Conselho Nacional de Desenvolvimento Científico e Tecnológico/CNPq, process 563256/2010-9 and Fundação de Amparo à Pesquisa do Estado de São Paulo/FAPESP, process 2010/52314-0. Rodrigo Marques Vieira and Luciano de Pinho Martins for invaluable help in realization of photographs.

\section{REFERENCES}

Burger, J. F. 2009. Tabanidae (Horse Flies, Deer Flies, Tabanos). In: Brown, B. V.; Borkent, A.; Cumming, J. M.; Wood, D. M.; Woodley, N. E. \& Zumbado, M. A. eds. Manual of Central American Diptera: Volume 1. Ottawa, Ontario, NRC Research Press, p.495-507.

Coscarón, S. \& Papavero, N. 2009. Catalogue of Neotropical Diptera. Tabanidae. Neotropical Diptera 16:1-199.

Cumming, J. M. 1992. Lactic Acid as an Agent for Macerating Diptera Specimens. Fly Times 8:7.

Cumming, J. M. \& Wood, D. M. 2009. Adult Morphology and Terminology. In: Brown, B. V.; Borkent, A.; Cumming, J. M.; Wood, D. M.; Woodley, N. E. \& Zumbado, M. A. eds. Manual of Central American Diptera: Volume 1. Ottawa, Ontario, NRC Research Press, p.9-50.

FAIRCHILD, G. B. 1967. Notes on Neotropical Tabanidae (Diptera). VII. The species described by C. R. W. Wiedemann. Pacific Insects 9:73-104. 1985. Notes on Neotropical Tabanidae (Diptera). XVIII. The genus Leucotabanus Lutz. Myia 3:299-331.

Fairchild, G. B. \& Philip, C. B. 1960. A Revision of the Neotropical Genus Dichelacera Subgenus Dichelacera, Macquart (Diptera, Tabanidae). Studia Entomologica 3:1-96.

HenriQues, A. L.; Krolow, T. K. \& Rafael, J. A. 2012. Corrections and additions to Catalogue of Neotropical Diptera. Tabanidae of Coscarón \& Papavero (2009). Revista Brasileira de Entomologia 56:277-280.

Henriques, A. L. \& RAFAEL, J. A. 1995. Revisão do gênero Neotropical Acanthocera Macquart (Diptera: Tabanidae). Acta Amazonica 23:403-440. 